\title{
Hastanelerin kurumsal sosyal sorumluluk faaliyetlerine yönelik içerik analizi
}

\author{
Aysun Yeşiltaş ${ }^{1}$, Ramazan Erdem¹ \\ ${ }^{1}$ Sağlık Yönetimi Bölümü, Süleyman Demirel Üniversitesi, Isparta, Türkiye
}

$\ddot{0} \mathrm{z}$

\begin{abstract}
Amaç: Bu çalışma ile hastanelerin kurumsal sosyal sorumluluk faaliyetlerini uygulama durumları ve uygulanan faaliyetlerin hangi alanlarda toplandığını belirlemek amaçlanmıștır. Yöntem: $\mathrm{Bu}$ çalışma, İç Anadolu Bölgesi'nde hizmet veren hastanelerin web sitelerinde belirli bir dönem süresince yayınlanan kurumsal sosyal sorumluluk faaliyetlerinin içerik analizini kapsamaktadır. Araştırmada, 'sgk.gov.tr' adresinden İç Anadolu Bölgesi'ne ait şehirler taranarak bulunan 72 özel hastane ve İç Anadolu Bölgesi'nde hizmet sunan Kamu Hastaneler Birlikleri'nin internet sayfaları taranarak elde edilen 115 devlet hastanesi incelenmiștir. Araștırma grubunu Kurumsal Sosyal Sorumluluk faaliyetlerini internet sitelerinde yayınlayan 95 hastane oluşturmuştur. Bulgular: Araştırma sonucunda, hastanelerin 100'ü (\%60.2) il merkezinde, 66'sı (\%39.8) ilçe merkezinde yer aldığı görülmüştür. Tüm hastanelerin \%57.2'sinin kurumsal sosyal sorumluluk faaliyeti uyguladığı ortaya çıkmıştır. Uygulanan faaliyetler sağlık eğitimi, kültürel faaliyet, sağlık hizmeti, toplumsal faaliyet ve çevresel faaliyet olarak gruplandırılmıştır. Hastanelerin kurumsal sosyal sorumluluk faaliyetleri içeren temalardan sağlık eğitimine yönelik faaliyetlerin ilk sırada yer aldığı görülmüştür. Sonuç: Sonuç olarak hastane web sitelerinden elde edilen bilgilere göre hastanelerin neredeyse yarısına yakınının (\%42.8) kurumsal sosyal sorumluluk faaliyetlerinde bulunmadığı görülmüştür. Dolayısıyla birincil amacı sağlık hizmeti sunmak olan hastanelerin, çalışanlarının kurumsal sosyal sorumluluk bilincine daha fazla vakıf olmaları adına bu konuda bilgilendirmeler yapılmalı, hastaneler ve çalışanları teşvik edilmeli, bu alanlarda etkinlik yapan hastaneler ödüllendirilmelidir.
\end{abstract}

Anahtar Kelimeler: Kurumsal sosyal sorumluluk, hastane, İç Anadolu Bölgesi

\section{Content analysis for hospital's corporate social responsibility activities}

\begin{abstract}
Aim: With this study, it was aimed to determine the applications of the institutional social responsibility activities of the hospitals and the areas where the activities are concentrated. Method: This study covers the content analysis of corporate social responsibility activities that are published for a particular time on the websites of the hospitals that serve in the Central Anatolia. In the study, 72 private hospitals which are found by searching on sgk.gov.tr, also 115
\end{abstract}

Yazının Geliş tarihi: 17.03.2017 Kabul tarihi: 22.06.2017

Yazışma adresi: Aysun Yeşiltaş, Süleyman Demirel Üniversitesi, Sağlık Yönetimi Bölümü, Isparta, Türkiye. Tel: 05448462048 E-posta: pelineren78@hotmail.com 
government hospitals which are found by searching on the internet address for Government Hospital Association in Central Anatolia, are examined. The study group is formed from 95 hospitals that have internet access and publish their corporate social responsibility. Results: The research showed, 100 hospitals (60.2\%) locates in city center and 66 of them (39.8\%) are in urban areas. It is found out that $57.2 \%$ of all the hospitals perform their activities. Performed activities are categorized as health education, cultural activity, and health service, social and environmental activity. Health education activities are seen at the top of the corporate social responsibility activities among all of them. Conclusion: As a result, based on the obtained information from hospital websites, it is seen that nearly half of the (42.8\%) hospitals don't do CSR. Therefore, workers of the hospitals whose primary aim is to serve health service, should be informed and encouraged to have awareness about social responsibilities and those hospitals which do these activities should be awarded for.

Keywords: Corporate Social Responsibility, hospital, Central Anatolia Region

\section{Giriş}

Kurumlar da tıpkı bireyler gibi içinde bulunduğu toplum, ülke ve uluslararası çevre bağlamında sosyal ve ekonomik sorumluluklara sahiptir. Bu nedenledir ki davranışlarını toplumsal sonuçları gözeterek gerçekleștirmek durumundadırlar. ${ }^{1} \mathrm{Bu}$ durumun bilincinde olan işletmelerde, devletin ve toplumun ihtiyacı olan sosyal nitelikli faaliyetlerin gerek düzenlenmesine gerekse desteklenmesine ek olarak, yasal ve ekonomik sorumluluklarının yanı sıra sosyal sorumluluklara da yönelerek devletin toplumsal refahı artırma gayesine ortak olmuşlardır. ${ }^{2}$

Özellikle kültürümüzde önemli bir yeri olan hayırseverlik belirli bir grubun ilgi alaniyken son yıllarda sosyal sorumluluk kavramı ile hem özel sektör hem de kamu kurumlarının gündeminde önemli bir yer edinmiş bulunmaktadır. Sosyal sorumluluk yaklaşımı 'kurumsal sosyal sorumluluk' (KSS) kavramı ile yeni bir boyut kazanmıș, yalnızca özel sektör kuruluşlarını değil, kamu kurumlarını, yerel yönetimleri ve eğitim kurumlarını bu yönde çalışmalar yapmaya teşvik eden güncel bir uygulama alanı olmuştur. ${ }^{3}$

KSS kavramın izleri 1950'lerde başlamış, 1960'lı yıllar modern KSS yılları olmuştur. 1960 ve 1970'lerde KSS tanımları artmış, 1980'lerde ise yeni tanım sayısı azalırken, bu konudaki ampirik çalışmalar artmış ve alternatif temalar ortaya çıkmaya başlamıştır. $\mathrm{Bu}$ alternatif temalar arasında kurumsal sosyal performans, iş etiği teorisi ve paydaş teorisi yer almaktadır. ${ }^{4}$ 1950'li yıllardan 1990'lı yıllara gelinceye kadar da işletmeler, iç çevrelerindeki sosyal sorumluluk paydaşlarına yönelmiş, işletmelerin sürdürülebilirliğinin hızla gündeme yerleşmesiyle, sosyal paydaşlarına giderek daha çok kaynak ayırmaya başlamışlardır. Böylece bugün geldiğimiz noktada tartışılan; işletmelerin kârlarını daha fazla arttırmaktan başka bir kurumsal sorumluluklarının olup olmadığı değil, kurumsal sosyal sorumluluğun kapsamına hangi nitelikteki faaliyetlerin girdiği ve girmesinin gerektiğidir. ${ }^{2}$

Yarım asırdan fazla süredir kurumsal sosyal sorumluluk kavramı literatürde yerini alırken Glavas ${ }^{5}$ kurumsal sosyal sorumluluk literatüründe görülen bazı boşluklara dikkat çekmiştir. Glavas'a göre;

-Kurumsal sosyal sorumluluk esas olarak makro ve kurumsal seviyelerde incelenmiş ancak KSS'nin çalışanları nasıl etkilediğini anlamaya yönelik yapılan çalışma sayısının yetersiz olduğu görülmüştür.

-KSS'nin çalışanlar üzerinde etkisi olduğu bilinmekte ancak bunun neden, nasıl ve ne zaman olduğu ile ilgili bilgilerin yetersiz olduğu görülmüştür.

-KSS'nin daha karmaşık modellerini öneren birkaç kavramsal model olmasına rağmen, örgütsel psikologların KSS'lar ile ortak olabilecekleri, ampirik test titizliğinden yoksun görülmüştür.. 
-KSS teorisi ve uygulama arasinda büyük boşluk vardır. İşletmeler KSS ile ilerlerken, aynı zamanda KSS uygulamaları ile uğraşmaktadır. $\mathrm{Bu}$, organizasyonel psikologların ileri sürdükleri ve teoriyi test edebilecekleri bir firsat sunmaktadır.

Kurumsal sosyal sorumluluk faaliyetlerinin hastanelerde uygulanma durumunu incelediğimiz çalışma kurumsal sosyal sorumluluğun tanımının ve kurumsal sosyal sorumluluğu oluşturan unsurların yer aldığı kavramsal çerçeve ve hastanelerin hangi kurumsal sosyal sorumluluk faaliyetlerine yöneldiğini ortaya koymaya çalışan bölümden oluşmaktadır.

\section{Kavramsal Çerçeve}

Son yllarda işletmelerin birincil görevlerine ek olarak toplumsal faaliyetlere de yönelmeleri literatürde kurumsal sosyal sorumluluk kavramının daha çok yer almasına neden olmuştur. Farklı tanımlamaların yapıldığı kurumsal sosyal sorumluluk kavramı ile ilgili pek çok mevcut tanım vardır ve bu tanımlar genel olarak gönüllüler, paydaşlar, sosyal, ekonomik, çevresel olmak üzere beş boyuta atıfta bulunmaktadır. ${ }^{6}$

Avrupa Komisyonu'nun tanımına göre kurumsal sosyal sorumluluk; "işletmelerin paydaşlarıyla birlikte gönüllü olarak etkileşimlerde ve işletme faaliyetlerinde, sosyal ve çevresel șeylerde birleșmesi" şeklinde tanımlamıștır. ${ }^{7}$ Diğer bir tanımla kurumsal sosyal sorumluluk; işletmenin sahip, ortak ve/veya yöneticilerinin işletmeyi yönlendirirken toplumun değer yargilarına göre hareket etmesi ve sosyal gereksinimlerin farkında olarak işletmeyi yönetmesidir. ${ }^{8}$

Kurumsal sosyal sorumluluğun kapsamında tüketicilere, hissedarlara, çalışanlara, tedarikçilere, çevreye, devlete ve rakiplere karşı sorumluluklar yer almaktadır. ${ }^{9}$ Kurumsal sosyal sorumluluk kavraminı 'herhangi bir organizasyonun hem iç, hem de diş çevresindeki tüm paydaşlara karşı etik ve sorumlu davranması, bu yönde kararlar alması ve uygulaması' șeklinde tanımlamak da mümkündür. ${ }^{10}$
İșletmelerin kurumsal sosyal sorumluluk kampanyaları sayesinde sağladıkları kazanımlar sadece ekonomik değildir. Günümüzde tüketiciler bir ürün veya hizmeti sadece kalitesi ve maddi değeri ile değil, bu ürünü üreten işletmelerin sosyal sorumluluk faaliyetleri ile birlikte değerlendirerek de tercih etmektedirler. ${ }^{11}$

Özelikle ilerleyen teknoloji, artan rekabet ortamında işletmeler diğer işletmelerden farklı olduğunu ortaya koymak amacıyla müșteri ve çalışan memnuniyetinin artmasını sağlayarak örgütün imajına ve itibarına önemli değerler kazandırmaktadır. ${ }^{12}$ Bununla birlikte zaman içinde bireylerin daha fazla bilinçlenmesi ve ayrıca çoğalan küresel sorunlar, toplumun işletmelerden beklentisini oldukça değiștirmiştir. Toplum, işletmelerden artık sadece ürün ve hizmet üretmelerini değil, bunun yanı sıra birer kurumsal vatandaş olarak toplumsal sorunlara da müdahale de bulunmalarını talep etmektedir. ${ }^{12}$

$\mathrm{Bu}$ talebin farkında olan kurumlar, hedef kitlelerin talep ve tutumunda görülen bu değişimler nedeniyle, toplumun refahını korumak ve geliştirmek yönünde kurumsal boyutta farklı kampanyaları önemsemeleri gerekliliğini kabullenmişlerdir. Kuruma karşı oluşabilecek olumsuz tepkileri önlemek için topluma ilişkin çeşitli sosyal sorumluluk kampanyaları yürütmeye başlamışlardır. ${ }^{1}$

Kurumsal sosyal sorumluluk denildiğinde, genellikle bir işletmenin sürdürülebilir büyüme temel hedefine yönelik olarak, doğayı ve çevreyi koruyacak önlemler alarak, üretimde bulunması anlaşılmaktadır. Oysaki bir işletmenin çevreye ve topluma karşı sorumlulukları yanı sıra doğrudan ve/veya dolaylı ilişki içerisinde bulunduğu ve işletme kararlarından ve faaliyetlerinden ciddi olarak etkilenebilecek tüm paydaşlara karşı sorumluluğu bulunmaktadır. ${ }^{10}$

Kurumsal sosyal sorumluluk politikalarını benimseyen ișletmelerin, çoğunlukla toplumsal olarak sorumlu işletmeler olduğuna inanılmaktadır. Kurumsal sosyal sorumluluk uygulamalarını benimseyen ilk nesil işletmeler, uzun vadede riski önlemek için daha çok belirli 
uygulamalara yönelirlerken, KSS uygulamalarını benimseyen ikinci nesil işletmeler, KSS'u yeni yönetim ve kurumsal yönetişim modellerinin bir parçası olarak kullanmışlardır. ${ }^{13}$

İşletmelerin iş ve pazarlama ahlâkına uygun davranma konusunda daha duyarlı hale gelmeleri, neden temelli ya da sosyal amaçlı programlara daha sıcak bakmaları ve hatta gönüllü olarak katılmalarının temelinde, bu tür çabalar içinde yer alan işletmelerin kamuoyu ve tüketiciler tarafindan daha olumlu algılanmaları yatmaktadır. ${ }^{14}$

Diğer taraftan günümüz insanları, değişim sürecinin hızına paralel olarak artık yalnızca ürünü ya da hizmeti değil ürün ya da hizmetin yarattığ değerleri de satın almaktadır. Rekabet avantajı yakalamak için farklılık yaratmanın zorunluluk haline geldiği bu çağda, işletmelerin kurumsal sosyal sorumluluk bilinci taşıması çok önemli bir farklılaşma kriteri olarak karşımıza çıkmaktadır. ${ }^{8}$ Tüketicilerde yaşanan bu değişim, sosyal sorumluluk faaliyetlerini artı birer maliyet olarak gören işletmelerin de konuya bakış açılarını değiştirmelerine neden olmuştur. Bugün kimi işletmelerin kendi sosyal sorumluluk projelerini geliştirirken kimilerinin de sponsorluk gibi yöntemlerde farklı projelerde yer aldıkları ve bu faaliyetlerini tüketicilere reklamlar aracılığıyla ilettikleri gözlemlenmektedir. Bu bağlamda, sosyal sorumluluk projelerinin işletmeler açısından tüketicilerin kendilerini tercih etmelerini sağlamak için uyguladıkları bir pazarlama yöntemi olarak kullanıldığını söylemek doğru olacaktır. ${ }^{15}$

Kurumsal sosyal sorumluluk kavramı işletmelerin görevlerinin yalnızca mal ve hizmet üreterek ekonomik sorumluluklarını yerine getirmekle sınırlı olmadığı, bunun yanında çalışanlarına, müşterilerine, hisse sahiplerine, rakiplerine, tedarikçilerine ve her şeyden önemlisi içinde yaşadığı topluma ve çevreye karşı yerine getirmesi gereken sorumluluklarının bulunduğunu ifade eder. 12

Toplumdan aldığını topluma geri vermek ve işletmenin faaliyetlerinde toplum yararını gözetmesi ilkelerine dayanan kurumsal sosyal sorumluluk anlayışı, işletmelerin ürettikleri ürün ve hizmetleri en iyi şartlarda pazarda tanıtmaları ve marka imajını güçlendirmeleri açısından önemli bir yere sahiptir. ${ }^{16}$ Kuruluşların, diledikleri kadar kaliteli ve çok sayıda üretim yapmaları için, gelişen teknoloji çok kısa sürede benzerlerinin üretilebilmesine imkan sağlamaktadır. Gerek tüketici beklentilerinin karşılanması gerekse rekabet koşullarının giderek artması, kuruluşların ana faaliyetlerini sosyal sorumluluk anlayışı çerçevesinde gerçekleștirmelerini zorunlu kılmıştır. ${ }^{8}$

$\mathrm{Bu}$ nedenle etkin bir "kurumsal sosyal sorumluluk" bilincine sahip şirketlerin en üst düzey yönetiminin bu konuda liderlik göstermesi, kendisi için bu kavramı ve sosyal paydaşlarını net olarak tanımlaması, bu konudaki faaliyetlerini sonuç odaklı olarak yürütmesi ve yapılanlar hakkında șeffafça hesap vermesi beklenmektedir. ${ }^{17}$

Kurumsal sosyal sorumluluk konusunu ciddiye alan şirketlere önemli kazanımlar sağlamaktadır. Yapılan çalışmalar sonucunda belirlenen faydalar şu şekilde sıralanmaktadır: ${ }^{17}$

-Bu şirketlerin marka değerleri ve dolayısıyla piyasa değerleri artmaktadır,

-Daha nitelikli personeli cezbetme, motive etme ve tutma olanağı doğmaktadır,

-Kurumsal öğrenme ve yaratıcılık potansiyeli artmaktadır,

-Özellikle bu konularda hassas yatırımcılara ulaşma imkanı oluştuğundan, gerek hisse değerleri artmakta, gerekse borçlanma maliyetleri düşmektedir,

-Yeni pazarlara girmekte ve müşteri sadakati sağlamada önemli avantajlar elde edilmektedir,

-Verimlilik ve kalite artışları yaşanmaktadır,

-Risk yönetimi daha etkin hale gelmektedir,

-Kamuoyunun ve kural koyucuların şirketin görüşlerine önem vermesi sağlanmaktadır. 
Kurumsal sosyal sorumluluk ekonomik, yasal, ahlaki ve gönüllü sorumluluklar olmak üzere dört unsurdan oluşmaktadır; ${ }^{18}$

Ekonomik sorumluluklar: Her şeyden önce işletmeler, toplumdaki temel ekonomik birimlerdir. Dolayısıyla temel görevleri, tüketiciler tarafından ihtiyaç duyulan ürün ve hizmetleri üretmek ve bu süreçte kabul edilebilir bir kâr elde etmektir. Ekonomik sorumluluk yerine getirilmeden diğer tüm sorumlulukların tartışmalı hale geleceğinden dolayl, işletmenin diğer tüm sorumluluklarının temelinde ekonomik sorumluluk yer almaktadır. ${ }^{19}$

\begin{tabular}{lcr}
\multicolumn{1}{c}{ Yasal } & sorumluluklar: & Toplum \\
işletmelerin & faaliyetlerinden & kar \\
sağlamalarını, & hatta maksimum & kara
\end{tabular} ulaşmalarını kabul ederken, bu amacı koșulsuz olarak onaylamamıștır. Ekonomik faaliyetlerini sürdürürken, işletmelerin belli yasal ve denetim kısıtlarını da göz ardı edemeyeceklerini vurgulanmıştır. İşletmenin ekonomik faaliyetlerini gerçekleştirirken uyması gereken ilke ve değerler yasa koyucular tarafından oluşturulmaktadır. ${ }^{20}$

Ahlaki sorumluluklar: Ahlaki sorumluluklar yasalarda yer almayan ve toplumun işletmelerden beklediği doğru ve adil davranışları içeren sorumluluklardır. Tüketiciler, çalışanlar, hissedarlar gibi sosyal paydaş gruplarının hak ve adaletle ilgili algılamaları; ahlaki sorumlulukların içeriğini oluşturmaktadır. ${ }^{16}$

Gönüllü sorumluluklar: Gönüllü sorumluluklar ise limitlerinin geniş olması ve etkilerinin firmaların ekonomik ve kar amacı güden oryantasyonları ile çelişmesiyle birlikte sorumlulukların en tartışmalı olanıdır. ${ }^{21}$

Kurumsal sosyal sorumluluk, topluma yönelik yükümlülüklerin bilinçli bir anlayış çerçevesinde yerine getirilmesi olarak değerlendirilebilmektedir. Dinamik bir yapıya sahip olan kurumsal sosyal sorumluluğun, toplumun değișen beklentileri ve değerleri ile beraber değiştiği ve buna bağlı olarak alanını genişlettiği görülmektedir. Bunlar, çalışanlara nitelikli iş ortamının sağlanması, tüketicilerin korunması, çevre kirliliğinin önüne geçilmesi ile yaşanabilir çevrelerin oluşturulması, paydaşlarının çıkarlarının korunması ve sosyal sorunların çözümü gibi alanlardır. ${ }^{22}$ İşletmeler eğitim, sağlık, kültür, çalışanların sosyal haklarının iyileştirilmesi gibi birçok alanda sosyal sorumluluk faaliyetleri gerçekleştirebilmektedirler. $\quad \mathrm{Bu}$ faaliyetlerden hepsini aynı anda gerçekleștirmek gerek maliyet gerekse işletmeye getireceği diğer yükler açısından zor olacağı için işletmeler genellikle bu faaliyetlerden bir ya da birkaçını seçerek, seçilen sosyal sorumluluk türleri üzerinde yoğunlaşmayı tercih etmektedirler. ${ }^{15}$

Kurumsal sosyal sorumluluk uygulamalarının toplumun birçok kesimi tarafından kabul görmesinin en önemli nedeni bu uygulamaların her kesimin lehine sonuçlar doğurduğunun uygulama ve araştırmalarla ortaya konulmuş ve paydaşlar tarafından anlaşılması olmuştur. ${ }^{10}$

Şirketlerin yerine getirmesi gereken ekonomik-verimli ve karlı olmak, hukukikanunlara uymak, etik-kanunların ötesinde toplumsal norm ve beklentilere uyumlu davranmak ve sosyal-toplumsal sorunların çözümü için gönüllü katkıda bulunmaktır. Kurumsal sosyal sorumluluk, doğrudan bu sorumlulukların son ikisini, ancak dolaylı olarak hepsini içermektedir. Çünkü, kurumsal sosyal sorumluluk, şirketlerin daha iyi bir toplum ve daha iyi bir çevre için gönüllü olarak katkıda bulunmalarını sağlamaktadır. ${ }^{17}$ Dolayısıyla hastaneler de iyi bir toplum için gerek maddi destek sağlayarak gerekse çalışanlarının katkılariyla kurumsal sosyal sorumluluk faaliyetlerinde bulunmalıdırlar.

Sağlıkta, kurumsal sosyal sorumluluk hastaneler ve diğer sağlık kuruluşlarının kaliteli sağlık hizmeti sunmak gibi konularda yararlı şeyler yapmaları için gereken etik bir zorunluluktur. Hastanelerde sosyal sorumluluk uygulamak kolay değildir, çünkü bazı paydaşların çıkarları, çoğu sağlık sistemlerinin temel hedeflerine karşı olabilir. $\mathrm{Bu}$ durum sağlık kuruluşlarının yönetiminde bazı zorluklara neden olmasına rağmen, birçok hastane yönetim kararlarında belirli girişimlerle sosyal sorumluluk kavramını uygulamaktadır. ${ }^{23}$ 
Karmaşık organizasyon olan hastaneler, kurumsal sosyal sorumluluğu ekonomik bakış açısıyla değil kamu hizmeti olarak görmeli kendi yönelimlerini belirlemek için hastalara imkan vermeli ve konuyla ilgili politikaları şeffaflığa dayanmalıdır. ${ }^{24}$

$\mathrm{Bu}$ doğrultuda hastanelerde uygulanabilecek kurumsal sosyal sorumluluk faaliyetlerine etik davranış kodlarının uygulanması, işyerinde olumlu eylem politikaları veya çevrenin gelişmesine aktif katkı sağlanması örnek olarak verilebilir. $^{23}$ Sağllk hizmeti sunan kuruluşların katkı sağlamış oldukları kurumsal sosyal sorumluluk faaliyetlerine örnek verecek olursak, İskandinavya'da sağlık hizmet veren Aleris Batı Afrika'daki Ebolo virisü ile mücadele çalışmalarını desteklemiş, 60 ülkede aktif olan Smile operasyonu ile birlikte yüz deformiteleri, yarık damak, yarık dudak gibi operasyonları ücretsiz gerçekleştirmiştir. Gine'de sağlık hizmetlerine katkı sağlamak amacıyla hastane ekipman ve sarf malzemeleri temini sağlamıştır. ${ }^{25}$ Bir diğer sağlık kuruluşu olan Amerikan Hastanesi, 2011 yılından itibaren yemek atıklarını hayvan barınaklarına göndermeye başlamış, Romanya'nın Dobruca Bölgesi'nde yaşayan muhtaç çocuklara sağlık taraması yapmıştır. ${ }^{26}$ Sağlık Bakanlığı'nın Dumansız Hava Sahası projesi de kurumsal sosyal sorumluluk faaliyetlerine örnek olarak gösterilebilir.

Araştırma, hastanelerin kurumsal sosyal sorumluluk alanında hangi faaliyetleri uyguladıklarını ve bu faaliyetlerin daha çok hangi alanlarda yapıldığını belirlemek amacıyla yapılmıştır. Ayrıca, araștırmaya konu olan hastanelerin mülkiyetleri, kuruluş yılları, yatak sayıları ile önemli bir iletişim aracı olan internet aracilığıyla KSS faaliyetlerini yayınlama durumları da incelenmiștir.

Araştırma, tüm dünyada büyüyen bir hizmet sektörü olan hastanelerin, hangi KSS faaliyetlerine yöneldiklerini belirlemek açısından önem arz etmektedir. Çalışma sonucunda hastanelerin daha az yöneldikleri KSS alanlarına dikkat çekilebilir ve KSS faaliyetleri uygulamayan hastanelerin KSS faaliyetlerine karşı farkındalıkları artırılabilir.

\section{Gereç ve Yöntem}

Çalışma hastanelerin web sayfalarında yayınlamış oldukları KSS faaliyetlerinin belirlenmesi amaciyla nitel araștırma yöntemlerinden içerik analizi olarak yapılmıştır. İçerik analizi, birbirine benzeyen verileri belirli kavramlar ve temalar çerçevesinde bir araya getirmek ve bunları okuyucunun anlayabileceği bir biçimde düzenleyerek yorumlamaktır. ${ }^{27}$ Araștırma tarama modeli kullanılarak yapılmıştır. Tarama modeli, geçmişte ya da halen var olan bir durumu olduğu şekliyle betimlemeyi amaçlamaktadır. ${ }^{28}$

Çalışma için göz önüne alınan sosyal sorumluluk alanları, hastanelerin web sitelerinde yer alan sosyal sorumluluk faaliyetlerinin belirli bir kodlama ve sınıflamaya göre değerlendirilmesi ile oluşturulmuştur. Kurumsal sosyal sorumluluk mesajı veren her paylaşım detaylı inceleme sonrası ait olduğu grupta toplanmıştır. Böylece her bir kurumsal sosyal sorumluluk faaliyet alanı tanımlanmış ve temalar oluşturulmuştur (Tablo 1).

Çalışma verileri SPSS 22.0 programı kullanılarak frekans analizlerine ve yüzdesel olarak dağılımlarına bakılmıștır.

Araştırmanın kapsamını İç Anadolu Bölgesi'nde hizmet sunan özel ve devlet hastaneleri oluşturmaktadır. Araştırmanın evrenini, 'sgk.gov.tr' adresinden İç Anadolu Bölgesi'ne ait şehirler taranarak bulunan 72 özel hastane ve İç Anadolu Bölgesi'nde hizmet sunan Kamu Hastaneler Birlikleri'nin internet sayfaları taranarak elde edilen 115 devlet hastanesi oluşturmaktadır. Çalışmada örneklem alınmamış, evrenin tamamına ulaşılmaya çalışılmıştır. Ancak internet sitesi olan ve KSS faaliyetlerini internet sitelerinde yayınlayan 95 hastanenin KSS faaliyetleri incelenmiștir. Kamu Hastaneler Birliklerine bağlı hastanelerin tescil edilen rolleri ve yatak sayıları Türkiye Kamu Hastaneleri Kurumu'nun yayınladığı sağlık tesislerinin güncel listesinden ${ }^{29}$ temin edilmiştir. İç Anadolu Bölgesi'nde birden fazla hastanesi 
olan özel șirketler hastane zinciri adı altında incelenmiştir.

Araştırma kapsamına alınan hastanelerin sadece web sitelerinde yer alan sosyal sorumluluk faaliyetlerinin incelenmiş olması, web sitelerinin belirli bir tarih aralığında (15 Kasım- 28 Aralık 2016) değerlendirilmiş olması araştırmanın sınırlılıklarını oluşturmaktadır. Web sitelerinde değerlendirme sonrasında değişikliler yapılmış olabilir.

Tablo 1. Analizde yer alan sosyal sorumluluk temaları

\begin{tabular}{ll} 
Sağlık Hizmeti & $\begin{array}{l}\text { Göz, diş taraması, şeker ölçümü, ücretsiz muayene, ücretsiz } \\
\text { sünnet yapılması, vs. }\end{array}$ \\
Kültürel Faaliyet & $\begin{array}{l}\text { Sportif faaliyetler, sponsorluklar, sanatsal faaliyetler, yarışmalar, } \\
\text { sergiler, kitap bağışları, kütüphane yapımı, vs. }\end{array}$ \\
Çevresel Faaliyet & $\begin{array}{l}\text { Çevre düzenlemesi, ağaç dikilmesi, çevre ile ilgili farkındalık } \\
\text { eğitimleri, hastanede her doğan bebeğe ağaç dikilmesi vs. }\end{array}$ \\
Sağlık Eğitimi & $\begin{array}{l}\text { Sağlık ve diğer konularda halka ve hastalara eğitimler, dergi } \\
\text { çlkarmak, kongre düzenlemek, stand açmak, vs. }\end{array}$ \\
Toplumsal Faaliyet & $\begin{array}{l}\text { Huzurevi ziyareti, ihtiyaç sahiplerine giysi/nakit yardımları, atık } \\
\text { pil toplama gibi toplumsal projelere katkı, vs. }\end{array}$ \\
\hline
\end{tabular}

\section{Bulgular}

Hastanelerle ilgili genel bulgular

İç Anadolu Bölgesi'nde yer alan hastanelerden beş devlet hastanesinin ve bir özel hastanenin internet sitesi bulunmamaktadır. Devlet hastanelerinin bir tanesi ise internet sitesindeki sorun nedeniyle incelemeye alınamamıştır. İncelenen 166 hastane ve hastane zincirinden kurumsal sosyal sorumluluk faaliyetlerinde bulunan, bu faaliyetlere web sitelerinde yer veren hastane sayısı 95'dir. $\mathrm{Bu}$ sayı tüm hastanelerin \%57.2'sini kapsamaktadır.

Araştırma kapsamında değerlendirilen hastanelerin 104'ü (\%62.7) devlet hastanesi, 55'i (\%33.1) özel hastane ve 7'si (\%4.2)özel sektöre ait hastaneler zinciridir. Hastanelerin 100'ü (\%60.2) il merkezinde, 66'sı (\%39.8) ilçe merkezinde yer almaktadır. Şehir dağılımına bakıldığında ise hastanelerin yoğunluğuna göre bulundukları iller sırasıyla Ankara (57), Konya (30), ve Kayseri'dir (16). Hastanelerin \%59'u 1921-1999 yılları arasında kurulmuş olup \%36.8'i 0-50 yatak sayısına sahiptir. Hastane zincirleri yatak sayısı değerlendirilmesine alınmamışlardır. Devlet hastanelerin rolleri incelendiğinde, \%24'ü C grubunda hizmet sunmaktadır (Şekil1-2).

\section{Temalara göre bulgular}

Çalışma kapsamında incelenen 166 hastanenin 159'unun (\%95.8) web sayfasında sosyal sorumluluğa yönelik bölüm bulunmamaktadır. Sosyal sorumluluk bölümü olan yedi hastaneden altı hastane sorumluluk bölümü aktif olarak kullanılmaktadır. Diğer hastanelerin sosyal sorumlulukla ilgili verileri 'Haberler, Duyurular, Basında Biz' gibi bölümleri içerisinde yer almaktadır. Bu bağlamda hastanelerin büyük çoğunluğunun kurumsal sosyal sorumluluk faaliyetlerine ilişkin haberlere genel haberler kısminda rastlanmaktadır diyebiliriz.

Çalışmanın dönem aralığında (15.11.2016-28.12.2016) yayınlanan tüm kurumsal sosyal sorumluluk faaliyetleri incelendiğinde; hastane zincirlerinin daha çok Kültürel Faaliyet alanına yöneldikleri görülmüştür. $\mathrm{Bu}$ kuruluşların birkaç 
hastaneden oluşan hastane zinciri olması, maddi olanaklarının daha fazla olması gibi avantajlar nedeniyle ilk siralarda yer aldıklarını düşünebiliriz.

Tablo 2'ye baktığımızda, hastanelerin yapmış oldukları faaliyetler Sağlık Eğitimi ve Kültürel Faaliyet temalarında, diğer temalardan daha fazla yer almıştır. Her bir tema ayrı ayrı incelenmiştir.

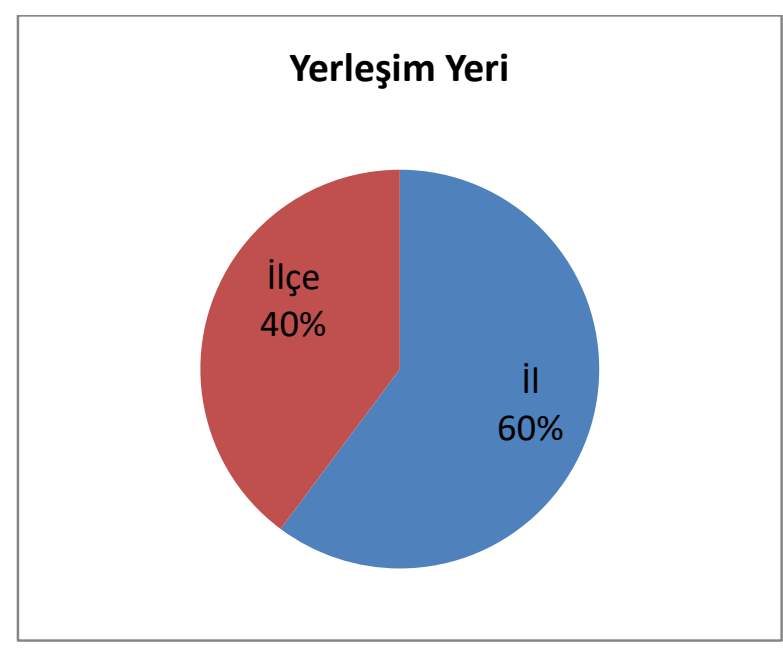

Şekil 1. Yerleşim yerine göre hastane sayıları

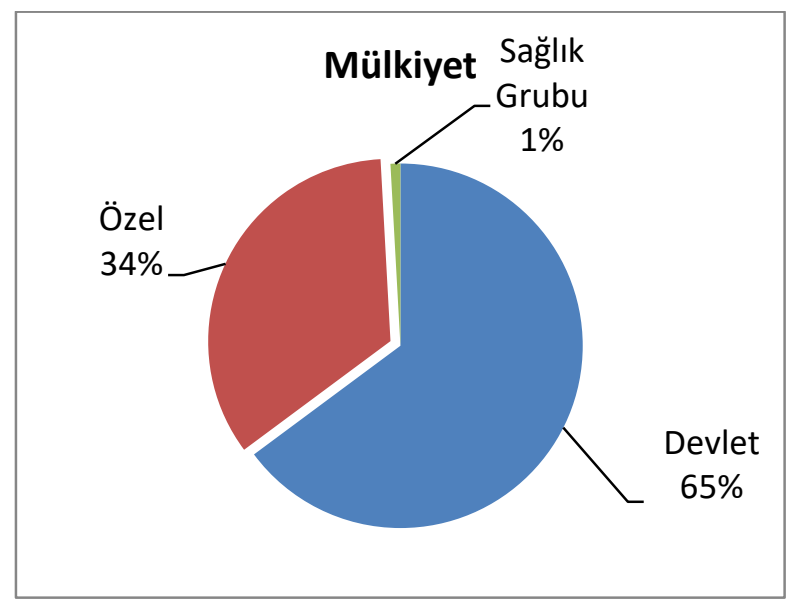

Şekil 2 Mülkiyete göre hastanelerin sinıflandırılması

Sağlık Eğitimi: Sağlık eğitimine yönelik faaliyetler, kurumsal sosyal sorumluluk temaları içerisinde hastanelerin en fazla yoğunlaştığı temadır. Sağlık eğitimi ile ilgili faaliyetler, tüm kurumsal sosyal sorumluluk faaliyetleri içerisinde \%46 ile ilk sıradadır. Sağlık eğitimi faaliyetleri arasında sırasıyla sağlıkla ve sağlık dışında konularda topluma eğitimler verme, stant açma, kongre düzenleme, dergi çıkarma yer almaktadır. Kurumsal sosyal sorumluluk faaliyetleri arasında en fazla sağlık eğitimine yönelen hastaneler devlet hastaneleri olmakla birlikte hastane zincirleri de halka yönelik eğitimler düzenlemektedir Sağlık eğitimi konularını değerlendirdiğimizde diyabet ve obezite konuları ilk sıralarda yer almaktadır. Özellikle Sağlık Bakanlığı'nın son dönemde diyabet ve obezite konusundaki çalışmalarına istinaden özellikle devlet hastanelerinin bakanlık isteği doğrultusunda bu konularda toplumu bilinçlendirme çalışmaları yaptığını söyleyebiliriz. Ayrıca Bebek Dostu Hastane çalışmaları çerçevesinde emzirme eğitimleri, gebe okulları özellikle devlet hastanelerinin yöneldiği sağlık eğitimi etkinlikleri içerisindedir.

Kurumsal sosyal sorumluluk kurum için tamamen kurumsallaştığı takdirde anlamlıdır. Bu toplumsal duyarlılık yaratan alanlarda sürdürülebilir gelişimin sağlanmasından, sosyal sorumluluk anlayışının kurumun günlük faaliyetlerinin ayrılmaz bir parçası haline gelmesini, yönetim tarafindan stratejilerin oluşturulmasını ve uygulama sistemlerine uyumlaştırılmasını ifade eder. ${ }^{30} \mathrm{Bu}$ bağlamda incelenen hastanelerin, özellikle sağllk eğitimine önem verdiğini ve toplumu sağlık konusunda bilgilendirme çalışmaları doğrultusunda kurumsallaştığını ifade edebiliriz.

Kültürel faaliyet: Sağlı alanında
toplumu bilgilendirmeye yönelik
konferanslar gerçekleştirilmesi, bültenler,
aylık dergiler hazırlanması, ücretsiz eğitim
programları düzenlenmesi, alanında uzman
kişilerin katıldığı televizyon ve radyo
programları düzenlenmesi hem toplumun
bilgilendirilmesi hem de sosyal sorumluluk
kapsamındaki görev ve sorumlulukların
yerine getirilmesi açısından önemlidir.

Tablo 2. Hastanelerin temalara göre faaliyet sayıları 


\begin{tabular}{lcc}
\hline Sağlık Ĕ̆itimi & 168 & 46 \\
\hline Kültürel Faaliyet & 103 & 28 \\
\hline Sağllk Hizmeti & 49 & 13 \\
\hline Toplumsal Faaliyet & 29 & 8 \\
\hline Çevresel Faaliyet & 17 & 5 \\
\hline Toplam & 366 & 100 \\
\hline
\end{tabular}

Aynı șekilde hastanenin bulunduğu șehirdeki voleybol, basketbol, futbol takımlarından birine sponsor olması, okullardaki spor müsabakalarına destek vermesi vb. etkinlikler yoluyla hastanenin bilinirliğini arttırılıp, hastaneye sempati duyulması sağlayabilmektedir. ${ }^{31} \mathrm{Bu}$ bağlamda Tablo 2'ye göre hastanelerin en fazla yoğunlaștığı temalar arasında 'kültürel faaliyetler' \%28'lik payla ikinci sıradadır. Kültürel faaliyetler ile ilgili hastanelerin web sitelerinden elde edilen verilere göre en fazla yapılan faaliyetler kitap okuma etkinlikleri, resim/şiir yarışmaları, tiyatro, kütüphane açma, yazarla söyleşi, okul tadilatı/yaptırma, sergiler, spor müsabakaları ve sponsorluklar yer almaktadır. Kurumsal sosyal sorumluluk temaları içerisinde kültürel faaliyetlere en fazla yönelen hastane zincirleridir. Devlet hastaneleri içerisinde ise bu temada en fazla faaliyet gösteren hastane bir eğitim araştırma hastanesidir. Özel hastanelerin ve hastane zincirlerinin devlet hastanelerine göre gelirlerinin belirli bir kısmını bu faaliyet alanında daha rahat kullanabildiğini söyleyebiliriz. Öyle ki devlet hastanelerinde bu alanda yapılan faaliyetler için harcanan giderleri gider bütçesinde gösterememektedirler. Dolayısıyla devlet hastaneleri çoğunlukla, maddi destek gerektirmeden hazırlanan kültürel faaliyetlere yönelmektedirler. Bu nedenle kültürel faaliyetler alanında devlet hastanelerinin etkinlikleri alt sıralardadır.

Sağlık hizmeti: Sağlık hizmetlerine yönelik faaliyetler, kurumsal sosyal sorumluluk temaları içerisinde \%13 ile kültürel faaliyetlerden sonra yer almaktadır. Sağlık hizmeti içerisinde bulunan faaliyetler arasında diș/göz taramaları, șeker/tansiyon ölçümü, sağlık taramaları ve sünnet yer almaktadır. Hastaneler bu alanda az personel ve malzemeyle kısa sürede ve sağlık kurumu dışında da sunabileceği sağlık hizmetlerini yapmıştır. Özellikle Sağlık Bakanlığı'nın obezite ve diyabetle mücadelesi doğrultusunda şeker ölçümü sağlık hizmeti etkinlikleri içerisinde ilk sıradadır. Yine Sağlık Bakanlığı'nın önderliğinde devlet hastanelerinin okullarda yaptığı diş taramaları ve florür dağıtımı faaliyetleri sağlık hizmeti teması etkinlikleri arasındadır.

Bazı ilaç firmaları da sağlık hizmeti konusunda sağlık kuruluşlarını desteklemektedir. Novartis firması sitma ve lepra gibi hastalıkları kontrol etme, yeterli hizmet alamayan hastalara ulaşmaya yönelik çalışmalar yapmaktadır. 2014 yılı itibarıyla bu çalışmalar sonucunda ulaşılan kişi sayısı ise 72 milyonu aşmıștır. ${ }^{32}$ Diğer bir firma olan Sanofi, Türk Diyabet Vakfı ve Sağlık Bakanlığı tarafından diyabet hastalığının yol açtığı zararları azaltmak amacıyla hayata geçirilen Diyabet 2020 projesine destek vermektedir. ${ }^{33}$

Toplumsal faaliyet: Kurumsal sosyal sorumluluk temaları içerisinde toplumsal faaliyetler, diğer temalar arasında \%8'lik payla çevresel faaliyetlerden sonra en az faaliyetin yapıldığı alandır. Toplumsal faaliyet teması kapsamında yer alan faaliyetler bağışlar, yardımlar, huzurevi ziyaretleri, serebral palsi, kan bağışı gibi konularda farkındalık etkinliklerini kapsamaktadır. Hastane zincirlerinin bu alanda daha etkin olduğu görülmüştür. 
Cevresel faaliyet: Hizmet kalitesine ve ekonomik olmaya önem veren hastaneler için son yıllarda ekolojik çevreyle uyumlu çevre dostu stratejiler benimsemek önem kazanmıştır. Özellikle yeşil hastane kavramının ortaya çlktığı bu dönemde hastaneler su, malzeme, atık yönetimi, otopark ve hastane bahçesinin yeşillendirilmesi, kırtasiye malzemelerinde israfın azaltılması gibi çevresel faaliyetlerde bulunmaktadırlar. ${ }^{34}$ Çalışmamızda da çevreye yönelik faaliyetler, toplam faaliyetlerin \%5'ini oluşturmaktadır. En az yapılan faaliyetler bu grupta yer almaktadır. Hastanelerin web sitelerinde yer alan çevreye yönelik kurumsal sosyal sorumluluk faaliyetleri ağaç dikimi, atık pil toplanması gibi etkinlikleri kapsamaktadır. Atık pil toplama kampanyasına destek verdiği web sitesi aracılığıyla görülen kuruluş bir hastane zinciridir. Ayrıca bir özel hastane ağaç dikme faaliyetini, hastanesinde doğan her bebeğe ağaç dikme faaliyeti şeklinde farklı bir kampanya ile desteklemektedir. Hastanelerin daha çok sağlı̆̆ iyileştirme ve geliştirmeye yönelik faaliyetlere yönelmeleri bu temaya yönelik faaliyetlerin az olmasına neden olmuş olabilir.

\section{Sonuç}

Diğer işletmeler gibi hastaneler de varlığını sürdürebilmek için gelișen, değișen stratejileri takip etmek zorundadırlar. Globalleşmenin etkisiyle tüm dünyadaki sağlı kuruluşları ile rekabet eden hastaneler, sadece sağlık hizmeti sunarak değil topluma yaptığı katkılarla da kendilerinden söz ettirmektedirler. Özellikle değişen müşteri profiliyle hastaneler, var olma çabalarını farklılaşma arayışlarına girerek karşılamaya çalışmaktadırlar. $\mathrm{Bu}$ nedenle hastaneler bilinirliklerini artırmak ve toplum nezdinde değerlerini yükseltmek adına kurumsal sosyal sorumluluk faaliyetlerine yönelmektedirler.

Kurumsal sosyal sorumluluk faaliyetleri, hem kamu hem de özel hastaneler tarafında toplum sağlığını iyileștirmeyi ve geliştirmeyi misyon edinmiş tüm sağlık kuruluşları için uygulanması zaruri etkinlikler haline gelmiştir. $\mathrm{Bu}$ bağlamda çalışmada hastanelerin kurumsal sosyal sorumluluk faaliyetlerine ne ölçüde önem verdiği tespit edilmeye çalışılmıştır. Hastanelerin web sitelerinden elde edildiği kadarıyla en çok kurumsal sosyal sorumluluk uygulamasının sağlık eğitimi olduğu ve bunu kültürel faaliyetlerin izlediği görülmüştür. Hastanelerin diğer kurumsal sosyal sorumluluk uygulamaları ise çevre faaliyetleri, eğitim faaliyetleri ve toplumsal faaliyetler olarak temalandırılmıştır.

Sonuç itibariyle hastane web sitelerinden elde edilen bilgilere göre hastanelerin neredeyse yarısına yakınının $(\% 42,8)$ kurumsal sosyal sorumluluk faaliyetlerinde bulunmadığı görülmüştür. $\mathrm{Bu}$ durum toplumun her kesimine hizmet sunan hastanelerin yapmış oldukları kurumsal sosyal sorumluluk faaliyetlerini web siteleri aracılığıyla yayınlamadığı anlamına da gelebilir. Ancak her iki durumda da hastanelerin toplumu bu konuda yetersiz bilgilendirdiğini söyleyebiliriz. Maddi çıkar ve katkı olmaksızın, sadece bilgilendirme ile yapılan sorumluluk faaliyetleri bile toplumun gelişmesine katkı sağlayacaktır. Dolayısıyla birincil amacı sağlık hizmeti sunmak olan hastanelerin, çalışanlarının kurumsal sosyal sorumluluk bilincine daha fazla vakıf olmaları adına bu konuda bilgilendirmeler yapılmalı, hastaneler ve çalışanları teşvik edilmeli, bu alanlarda etkinlik yapan hastaneler ödüllendirilmelidir. Temiz, güvenli çevrenin sağlığı da olumlu şekilde etkilediğini düşündüğümüzde hastaneler bu alanda daha fazla etkinlik yapmalı, bulundukları bölgelerin orman müdürlükleri ile işbirliği içerisinde ağaç dikme etkinliklerini artırmalı, çevre konusunda da eğitimler vermelidirler. Ayrıca bazı küçük ilçe hastaneleri bulundukları şehirde kültürel faaliyetleri destekleyecek sayılı kuruluşlardan biri olabilir. Dolayısıyla özellikle bu hastanelerin bölgelerindeki kültürel faaliyetleri destekleyen projelere katkıda bulunmaları ve bilinçli ve sağlıklı bir toplum için özellikle diğer kamu kuruluşları ile işbirliği içinde bu tür faaliyetleri desteklemelidirler. Yine hastaneler toplumla iletişimini sağlayan halkla ilişkiler birimlerini, daha aktif kullanarak kurumsal sosyal sorumluluk faaliyetlerini artırabilirler. Ek olarak kurumsal sosyal sorumluluk bilincini 
artırmak adına hastane web sitelerinde kurumsal sosyal sorumluluk bölümünün olması bu konuya verilen önemi artıracaktır. Sağlık Bakanlığı'nın önderliğinde yapılan sağlık eğitimleriyle birlikte hastaneler bölgelerinde eksikliğini tespit ettikleri sağlıkla ilgili eğitimleri düzenli olarak vererek kurumsal sosyal sorumluluk faaliyetlerini destekleyebilirler.

\section{Kaynak}

1. Vural ZB, Coşkun G. Kurumsal sosyal sorumluluk ve etik. Gümüșhane Üniversitesi İletişim Fakültesi Elektronik Dergisi 2011;1:61-87.

2. Yönet E. Kurumsal sosyal sorumluluk anlayışında son dönemeç: stratejik sorumluluk. Balıkesir Üniversitesi Sosyal Bilimler Enstitüsü Dergisi 2005;8(13):239-265.

3. Saran M, Coşkun G, İnal Zorel F, Aksoy Z. Üniversitelerde sosyal sorumluluk bilincinin geliştirilmesi: Ege Üniversitesi topluma hizmet uygulamaları dersi üzerine bir araștırma Journal of Yasar University 2011;22(6):3732-3747.

4. Carroll AB. Corporate social responsibility. Business \& Society 1999:38(3):268-295.

5. Glavas A. Corporate social responsibility and organizational psychology: an integrative review. Frontiers in Psychology 2016;7:1-13.

6. Dahlsrud A. How corporate social responsiblity is defined: an analysis of 37 definitions. Corporate Social Responsibility \& Environmental Management 2006;15(1):1-13.

7. European Comission. Corporate Social Responsibility: A Business Contribution to Sustainable Development. 2002. Erişim: http://trade.ec.europa.eu/,Erişim Tarihi:14.11.2016.

8. Solmaz B. işletmelerin değişen konumuyla gelişen kurumsal sosyal sorumluluk bilinci ve Türkcell'in desteklediği 'çağdaş Türkiye'nin çağdaş kızları' projesinin genel bir değerlendirmesi. Selçuk İletişim Dergisi 2005;4(1):116-125.

9. Sert NY. Kurumsal sosyal sorumluluk ve aktivizm ilişkisinin araştırılması: Türkiye'de özel sektör, kurumsal sosyal sorumluluk ve aktivizm ilintisi. (Doktora Tezi), Serra Görpe; yayınlanmamış tez, İstanbul 2012.

10. Aktan CC, Börü D. Kurumsal sosyal sorumluluk. Kurumsal sosyal sorumluluk işletmeler ve sosyal sorumluluk. Ed: Aktan CC, İGİAD Yayınları, İstanbul. 2007.

11. Süzen E, Akın I. Kurumsal sosyal sorumluluk uygulamalarının kurumlara olan katkıları üzerine bir uygulama. 15. Ulusal İşletmecilik Kongresi Bildiriler Kitabi. 2016,ss.485-495.

12. Erkman T, Şahinoğlu F. Kurumsal sosyal sorumluluk faaliyetlerine ilişkin çalışan algıları ile örgütsel bağlılığın hizmet sektöründe incelenmesi. Marmara Üniversitesi İIBF Dergisi 2012;33(2):267294.

13. Papafloratos, T.Do Corporate Social Responsibility Initiatives Influence the Consumers?

Erişim:pdfs.semanticscholar.org/e18e/c 04805c83e610c2fd5f48afc2267fc80f425 .pdf, Erişim Tarihi:12.10.2016.

14. Torlak Ö. Tüketicilerin kurumsal sosyal sorumluluk çabalarını algılamaları. Kurumsal sosyal sorumluluk işletmeler ve sosyal sorumluluk. Ed:Aktan CC, İGİAD Yayınları. İstanbul, 2007.

15. Ateşoğlu İ, Türker A. Konaklama işletmelerinin sosyal sorumluluk faaliyetlerine yaklaşımı: Muğla ili örneği. Süleyman Demirel Üniversitesi Íktisadi ve Ídari Bilimler Fakültesi Dergisi 2010;15(3):207-226.

16. Özdemir Ö. Kurumsal sosyal sorumluluğun marka imajına etkisi. İstanbul Ticaret Üniversitesi Sosyal Bilimler Dergisi 2009;8(15):57-72.

17. Argüden Y. Kurumsal sosyal sorumluluk. Kurumsal sosyal sorumluluk işletmeler ve sosyal sorumluluk. Ed:Aktan CC, İGİAD Yayınları İstanbul. 2007. 
18. Carroll AB. The pyramid of corporate social responsibility: toward the moral management of organizational stakeholders. Business Horizons 1991 Erişim: http://wwwrohan.sdsu.edu/faculty/dunnweb/rprnts .pyramidofcsr.pdf. Erişim Tarihi:12.11.2016.

19. Büyükyllmaz Y, Fidan O. Kurumsal sosyal sorumluluk: kavramsal bir bakıș. Uluslararası İsletme ve Yönetim Dergisi 2015;(3):364-381.

20. Ulu AS. Kurumsal sosyal sorumluluk: bir alan çalıșması (Yüksek Lisans Tezi) Mustafa Taşlıyan, yayınlanmamış tez Kahramanmara. 2007.

21. Jamali D, Mirshak R. Corporate social responsibility (csr): theory and practice in a developing country context. Journal of Business Ethics 2007;72:243-262.

22. Becan C. Kurumsal sosyal sorumluluk kavramının paydaş teorisi ve iletişim yaklaşımı açısından değerlendirilmesi: bankaların basın bültenlerine yönelik bir içerik analizi. Selçuk İletişim 2011;7(1):16-35.

23. Brandao C, Rego G, Duarte I, Nunes R. Social responsibility: a new paradigm of hospital governance? Health Care Anal, 2013;21:390-402.

24. Abreu R, David F. ve Crowther D. Corporate Social Responsibility is Urgently Needed in Health Care. Social Responsibility Journal, 2005;1(3-4): 225240.

25.Corporate Social Responsibility in Healthcare \& Care Services 2015 Developing sustainable healthcare \& care services in Scandinavia Erişim:https://www.unglobalcompact.or g/system/attachments/cop_2015/17006 1/original/Aleris_Corporate_social_respo nsibility_in_healthcare_care_services_2 015.pdf?1435148447 Erişim tarihi: 28.05:2017.

26.Amerikan Hastanesi. E. Erişim:http://www.amerikanhastanesi.c om.tr/Kurumsal.aspx?PageID=5 rişim tarihi: 28.05.2017
27. Yıldırım A, Şimşek H. Sosyal bilimlerde nitel araştırma yöntemleri. Genişletilmiş 9. Baskı, Seçkin Yayıncılık. Ankara, 2013.

28. Karasar N. Araştırmada rapor hazırlama. Ankara:3A Araştırma Eğitim Danışmanlık Ltd. 1994.

29. Türkiye Kamu Hastaneler Kurumu, http://www.tkhk.gov.tr/DB/6/766_DB_6 _kamu-hastane-birliklerine-baglihastanelerin-yatak-sayilari-rol-tanimlarive-listeleri-sunum-rehberi. Erişim tarihi:12.12.2016.

30. Şatır Ç, Öztekin Z. Sosyal sorumluluk ve etik. İstanbul Üniversitesi İletişim Fakültesi Dergisi 2005;22:143-152.

31. Yurdakul NB, Coşkun G, Öksüz B. Hastanelerde halkla ilişkiler: İzmir ili özel hastaneler örnekleminde halkla ilişkiler birimlerinin yapı-işlev ve uygulamalarına yönelik bir araștırma. Eskişehir Osmangazi Üniversitesi IIBF Dergisi.2007;2(1):31-46.

32. Kurumsal Sorumluluk, Novartis Erişim yeri:

www.novartis.com.tr/hakkimizda/kuru msal-sorumluluk. Erişim tarihi:29.05.2017.

33. Sorumluluğumuz, Sanofi. Erişim yeri: http://www.sanofi.com.tr/l/tr/tr/layout .jsp?scat=A92D102B-46B7-40D1-B8339F20C8E9C92E\#p3 Erişim tarihi: 29.05.2017.

34. Terekli G, Özkan O, Bayın G. Çevre dostu hastaneler: hastaneden yeşil hastaneye. Ankara Sağlık Hizmetleri Dergisi 2013;12(2):37-54. 